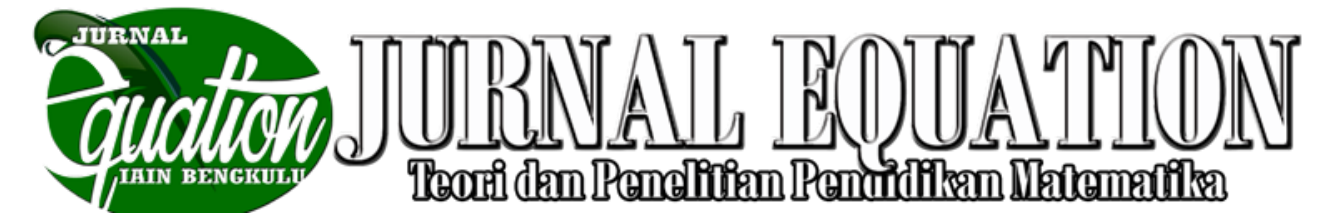

Volume 2 Nomor 2, September 2019, ISSN 2599-3291 (Cetak), ISSN 2614-3933

\title{
Penggunaan Teknik Scaffolding Pada Pembelajaran Matematika Untuk Meningkatkan Kemampuan Pemahaman Matematik Pada Siswa SMP
}

\author{
Irma Rachmawati , Alan Purnama \\ Mahasiswa Jurusan Pendidikan Matematika IKIP SILIWANGI \\ rachmawatiirma1@gmail.com
}

\begin{abstract}
ABSTRAK
Penelitian ini dilatarbelakangi oleh kemampuan pemahaman matematik siswa SMP yang rendah. Padahal kemampuan pemahaman matematik ini sangatlah penting dalam matematika, dengan pemahaman matematik akan dapat menumbuhkan kemampuan siswa dengan baik dan benar pada setiap permasalahan matematika yang muncul. Oleh karena itu, perlu dilakukan upaya untuk meningkatkan kemampuan tersebut. Salah satu upaya yang dapat dilakukan adalah menggunakan metode pembelajaran Teknik Scaffolding. Penelitian ini bertujuan untuk mengetahui peningkatan kemampuan pemahaman matematik siswa dan untuk mengetahui sikap siswa terhadap pembelajaran dengan menggunakan metode teknik scaffolding. Metode yang digunakan dalam penelitian ini adalah kelompok kontrol pretes-postes. Populasi dalam penelitian ini adalah seluruh siswa kelas VIII di salah satu MTs di Kabupaten Bandung Barat tahun ajaran 2018/2019. Sampel yang diambil secara acak dua kelas yaitu kelas eksperimen dan kelas kontrol. instrumen yang digunakan adalah instrument tes kemampuan pemahaman matematik, angket, serta lembar observasi. Berdasarkan hasil analisis data diperoleh kesimpulan bahwa: 1). Peningkatan kemampuan pemahaman matematika siswa yang menggunakan teknik scaffolding lebih baik daripada siswa yang pembelajarannya menggunakan pembelajaran konvensional, 2) Kualitas peningkatan kemampuan pemahaman matematik siswa dengan menggunakan teknik scaffolding berada pada kategori sedang, 3) Sikap siswa terhadap pembelajaran matematika dengan teknik scaffolding adalah seluruh siswa memberikan sikap yang positif.
\end{abstract}

Kata kunci: Kemampuan Pemahaman Matematik, Metode Teknik Scaffolding

\section{PENDAHULUAN}

Matematika mempelajari tentang pola keteraturan, tentang struktur yang terorganisasikan. Hal itu dimulai dari unsur-unsur yang tidak terdefinisikan (undefined terms, basic terms, primitive terms), kemudian pada unsur yang didefinisikan, ke aksioma/postulat dan akhirnya pada teorema Ruseffendi (1988: 50). Dalam matematika terdapat konsep prasyarat sebagai dasar untuk memahami topik atau konsep selanjutnya. Untuk dapat memahami struktur-struktur yang abstrak serta hubunganhubungan, diperlukan pemahaman akan konsep sebelumnya yang menjadi prasyarat harus benar-benar dikuasai agar dapat memahami konsep-konsep selanjutnya.

Selain itu dalam panduan KTSP (Kurukulum Tingkat Satuan Pendidikan) untuk mata pelajaran matematika, (BSNP, 2006) dijabarkan bahwa mata pelajaran matematika bertujuan agar peserta didik memiliki kemampuan sebagai berikut: 1). Memahami 


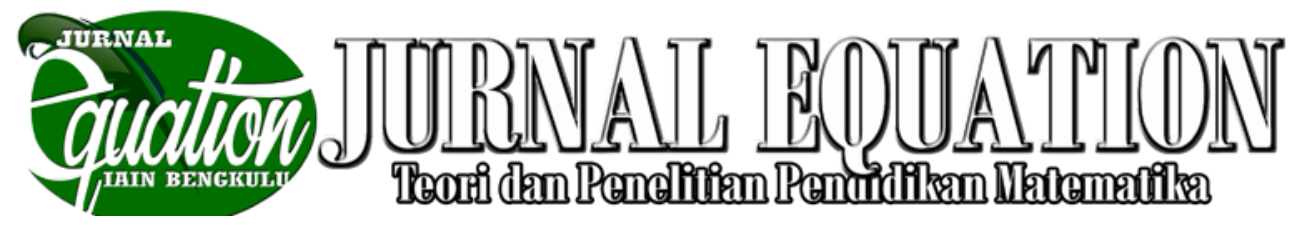

Volume 2 Nomor 2, September 2019, ISSN 2599-3291 (Cetak), ISSN 2614-3933

konsep matematika, menjelaskan keterkaitan antar konsep dan mengaplikasikan konsep atau algoritma, secara luwes, akurat, efisien dan tepat dalam pemecahan masalah, 2). Menggunakan penalaran pada pola dan sifat, melakukan manipulasi matematika dalam membuat generalisasi, menyusun bukti atau menjelaskan gagasan dan pernyataan matematika, 3). Memecahkan masalah yang meliputi kemampuan memahami masalah dan merancang model matematika, menyelesaikan model dan menafsirkan solusi yang diperoleh, 4). Mengkomunikasikan gagasan dengan simbol, tabel, diagram, atau media lain untuk memperjela keadaan atau masalah, dan 5). Memiliki sikap menghargai kegunaan matematika dalam kehidupan, yaitu memiliki rasa ingin tahu, perhatian dan minat dalam memperlajari matematika, sikap ulet dan percaya diri dalam pemecahan masalah.

Berdasarkan uraian di atas, tujuan matematika adalah agar siswa dapat memecahkan persoalan sehari-hari, dalam arti konsep matematika yang diperolehnya bisa diterapkan tidak hanya di sekolah ketika ia belajar matematika. Siswa diharapkan dapat mampu menerapkan matematika di dunia nyata dalam menghadapi persoalan sehari-hari dan juga mampu menerapkan matematika dalam mata pelajaran lain. Selain itu, siswa diharapkan mampu mengaitkan antara konsep matematika yang satu dengan konsep matematika yang lainnya, karena matematika merupakan ilmu terstruktur.

Rendahnya tingkat penguasaan konsep matematika disebabkan oleh beberapa faktor salah satunya adalah pembelajaran yang digunakan di Indonesia pada umumnya bersifat konvensional. Menurut Zulkarnain (Nengsih, 2009: 2), "Sampai saat ini pendekatan pembelajaran matematika di Indonesia masih menggunakan pendekatan konvensional atau mekanistik yang menekankan pada latihan soal, prosedur dan penggunaan rumus secara algoritma". Akibatnya yang akan ditimbulkan adalah pemahaman konsep siswa dalam belajar matematika menjadi kurang optimal serta suasana kelas yang kurang menyenangkan. Oleh karena itu, mereka kurang terbiasa memecahkan masalah yang ditemui di sekeliling mereka. Dengan pembelajaran konvensional akan membuat anak pasif dan tidak sepenuhnya terlibat dalam proses pembelajaran. Kemampuan siswa dalam pemahaman konsep-konsep matematika belum seperti yang diharapkan. Machmudin (2004: 66), "Dalam upaya mencari solusi kelemahan penguasaan matematika pada siswa, maka dalam proses pembelajaran yang menekankan pada pemahaman konsep".

Salah satu alternatif pembelajaran yang dapat digunakan adalah metode pembelajaran teknik scaffolding. Metode pembelajaran teknik scaffolding merupakan sebuah skenario pembelajaran dua arah atau student center (inquiry). Penggunaan metode ini memberikan kebebasan belajar kepada siswa untuk mencapai tahapan yang dapat di raihnya. Melalui pembelajaran ini juga, siswa dihadapkan pada masalah kontekstual yang mengantar siswa mengenal objek matematika, melibatkan siswa melakukan proses matematika secara aktif.

Berdasarkan pada pemaparan diatas penulis menyimpulkan bahwa kemampuan pemahaman penting untuk ditingkatkan, dan pembelajaran matematika dengan teknik scaffolding merupakan salah satu metode pembelajaran yang bisa digunakan. Oleh karena itu penulis merasa terdorong untuk melakukan penelitian mengenai dua permasalahan tersebut, permasalahan tersebut berlaku untuk semua siswa di Indonesia, karena keterbatasan waktu, biaya, dan tenaga yang dimiliki oleh peneliti, maka penelitian ini hanya dilakukan untuk salah satu sekolah. Judul yang diambil dalam 


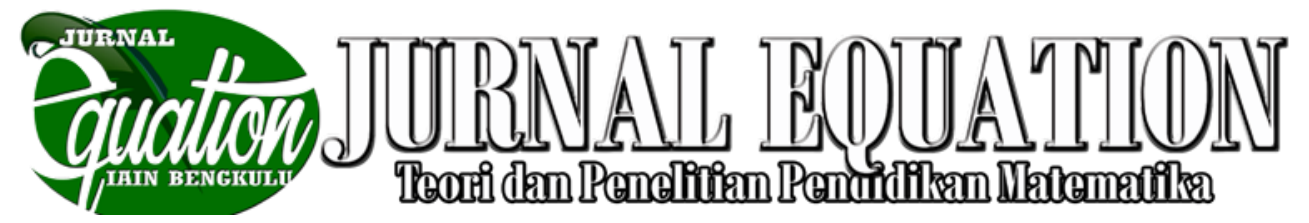

Volume 2 Nomor 2, September 2019, ISSN 2599-3291 (Cetak), ISSN 2614-3933

penelitian ini penggunaan teknik scaffolding pada pembelajaran matematika untuk meningkatkan kemampuan pemahaman matematik pada siswa SMP.

Berdasarkan uraian tersebut, maka rumusan masalah dalam penelitian ini adalah apakah peningkatan kemampuan pemahaman matematik siswa yang memperoleh pembelajaran dengan menggunakan teknik scaffolding lebih baik daripada peningkatan kemampuan pemahaman matematik siswa yang memperoleh pembelajaran dengan menggunakan pembelajaran konvensional?, bagaimana kualitas peningkatan kemampuan pemahaman matematik siswa yang pembelajarannya menggunakan teknik scaffolding?, dan bagaimana sikap siswa terhadap pembelajaran matematika dengan teknik scaffolding?.

Tujuan yang ingin dicapai dari pelaksanaan penelitian ini adalah untuk mengetahui apakah peningkatan kemampuan pemahaman matematik siswa SMP pada pembelajaran matematika yang menggunakan teknik scaffolding lebih baik daripada siswa yang menggunakan pembelajaran konvensional, untuk mengetahui kualitas peningkatan kemampuan pemahaman matematika siswa yang pembelajarannya menggunakan tenik scaffolding dan untuk mengetahui apakah siswa bersikap positif terhadap penggunaan teknik scaffolding dalam pembelajaran matematika.

\section{KERANGKA PEMIKIRAN DAN HIPOTESIS}

Pemahaman konsep matematika merupakan landasan dasar dalam belajar matematika, oleh karena itu dalam pembelajaran matematika yang ditekankan terlebih dahulu adalah pemahaman konsep yang baik dan benar. Agar siswa lebih memahami konsep dengan baik dan benar, para guru matematika harus berusaha untuk mewujudkan keabstrakan konsep menjadi lebih konkret.

Pemahaman konsep adalah kemampuan siswa dalam mengklasifikasi konsep dan mengimplementasikan konsep berdasarkan contoh dan bukan contoh, dan siswa dapat mengungkapkan suatu konsep dengan menggunakan kata-kata sendiri disertai alasannya. Masalah yang sering terjadi yaitu siswa hafal suatu konsep, tetapi siswa tidak bisa menerapkan suatu konsep dalam pemecahan masalah. Selain itu kebiasaan guru langsung memberikan suatu konsep secara baku, tanpa menjelaskan pembentukan konsep itu berlangsung. Akibatnya ketika siswa mengerjakan soal yang berbeda dengan yang diberikan contoh oleh guru atau siswa harus mencari konsep yang belum diketahui dalam soal, siswa belum mampu mengerjakannya.

Salah satu cara aga siswa mudah memahami konsep matematika, yaitu dengan melibatkan siswa secarta aktif dalam pembelajaran. Pembelajaran matematika melibatkan siswa aktif dapat meningkatkan kemampuan berpikir siswa dalam memahami sebuag konsep serta dapat menyelesaikan masalah dengan keterampilan-keterampilan dan ilmu pengetahuan yang telah dimiliki. Menurut Schoenfel (Turmudi, 2009), belajar dengan pemahaman membuat belajar berikutnya menjadi lebih mudah. Matematika membuat masuk akal dan lebih mudah untuk diingat, serta dan menerapkan kapan siswa mengaitkan pengetahuan baru dengan pengetahuan yang dimilikinya dengan cara-cara yang bermakna.

Para guru matematika dapat mencoba berbagai metode yang dapat membangkitkan kemampuan berpikir siswa, salah satunya adalah metode teknik scaffolding. Metode pembelajaran teknik scaffolding merupakan sebuah skenario pembelajaran dua arah atau student center (inquiry). Penggunaan metode ini memberikan 


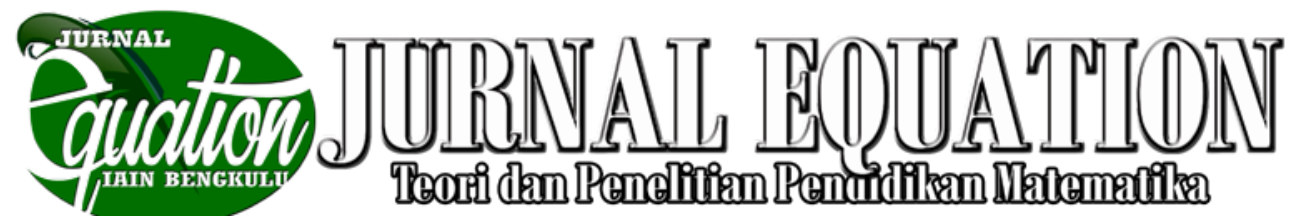

Volume 2 Nomor 2, September 2019, ISSN 2599-3291 (Cetak), ISSN 2614-3933

kebebasan belajar kepada siswa untuk mencapai tahapan yang dapat diraihnya. Melalui pembelajaran ini juga, siswa dihadapkan pada masalah kontekstual yang mengantar siswa mengenal objek matematika, melibatkan siswa melakukan proses matematika secara aktif.

Aspek yang penting dalam teknik scaffolding adalah menunjukan pemahaman, dimana kemampuan siswa dengan pengetahuan baru dan dibarengi dengan proses pembimbingan dan akibatnya siswa mampu menyelesaikan tugas secara mandiri (Nurmasari, 2005: 7). Scaffolding merupakan jembatan yang digunakan untuk menghubungkan apa yang sudah diketahui oleh siswa (kemampuan aktual) dengan sesuatu yang baru yang akan dikuasai atau diketahui siswa (kemampuan potensial) (Priyatni, 2008:207). Dalam proses scaffolding guru membantu penguasaan tugas dan konsepkonsep yang sulit dicerna siswa.

\section{METODOLOGI PENELITIAN}

Metode yang digunakan adalah metode eksperimen dengan desain kelompok kontrol pretest-posttest. Populasi penelitian ini adalah siswa kelas VIII MTs Bongas tahun ajaran 2018/2019 dengan sampel yang dipilih dua kelas secara acak yaitu siswa kelas VIII-B sebagai kelas eksperimen dan siswa kelas VIII-C sebagai kelas kontrol.

Dalam penelitian ini yang menjadi variabel bebas adalah metode teknik scaffolding sedangkan variabel terikatnya adalah kemampuan pemahaman matematik siswa. Instrumen yang digunakan berupa tes dan non tes. Instrumen tes yang digunakan adalah tes kemampuan pemahaman matematik siswa. Instrumen non tes yang digunakan adalah skala sikap dan lembar observasi. Tes yang digunakan dalam penelitian ini adalah tes kemampuan berpikir kreatif berupa tes awal (pretest) dan tes akhir (posttest). Tes yang digunakan dalam penelitian ini adalah tipe tes uraian. Uji coba dilaksanakan di kelas VIII-B MTs Bongas. Berdasarkan analisis data hasil uji coba, semua soal layak untuk dijadikan sebagai instrumen penelitian. Skala yang digunakan adalah skala sikap model Likert terdiri atas empat pilihan (sangat setuju, setuju, tidak setuju, dan sangat tidak setuju) dan menghilangkan opsi netral. Setelah data diperoleh, dilakukan analisis data menggunakan bantuan software SPSS versi 21.0 dengan perincian sebagai berikut:

\section{Analisis Data Hasil Pretes}

\section{1) Uji Normalitas}

Uji normalitas data pretes kelas eksperimen dan kelas kontrol untuk mengetahui apakah data skor pretes berasal data subjek berdistribusi normal atau tidak.Uji 1-Sample K-S (Shapiro-Wilk) dengan taraf signifikansi 5\% adalah uji normalitas yang digunakan dalam penelitian ini dengan bantuan software SPSS versi 21.0.Perumusan hipotesis pengujian normalitas menurut Uyanto (2009: 40) untuk data pretes adalah.

$\mathrm{H}_{0}$ : Data skor pretes berasal dari populasi yang berdistribusi normal

$\mathrm{H}_{1}$ : Data skor pretes berasal dari populasi yang tidak berdistribusi normal

Uji normalitas dengan menggunakan uji Shaphiro-Wilk dengan taraf signifikansi $5 \%$. Untuk kriteria pengujiannya sebagai berikut.

1) Nilai signifikansi (sig.) pengujian data lebih kecil dari 0,05 , maka $\mathrm{H}_{0}$ ditolak.

2) Nilai signifikansi (sig.) pengujian data lebih besar atau sama dengan dari 0,05, maka $\mathrm{H}_{0}$ diterima.

\section{3) Uji Homogenitas Dua Varian}

Setelah uji normalitas data pretes menunjukan kedua kelas berasal dari populasi yang berdistribusi normal, selanjutnya dilakukan uji homogenitas varians untuk mengetahui 


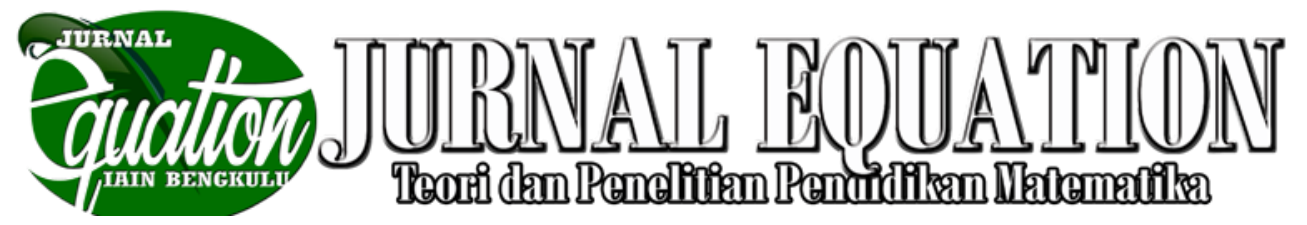

Volume 2 Nomor 2, September 2019, ISSN 2599-3291 (Cetak), ISSN 2614-3933

apakah kedua data pretes mempunyai varians homogen atau tidak.Perumusan hipotesis yang digunakan pada uji homogenitas data pretes adalah sebagai berikut.

$\mathrm{H}_{0}$ : Tidak terdapat perbedaan varians antara kelas eksperimen dan kelas kontrol.

$\mathrm{H}_{1}$ : Terdapat perbedaan varians antara kelas eksperimen dan kelas kontrol.

Uji homogenitas yang digunakan adalah uji Lavene dengan taraf signifikansi $5 \%$. Kriteria pengujiannya adalah sebagai berikut.

a. Nilai signifikansi (sig.) pengujian data lebih kecil dari 0,05 , maka $\mathrm{H}_{0}$ ditolak.

b. Nilai signifikansi (sig.) pengujian data lebih besar atau sama dengan 0,05 , maka $\mathrm{H}_{0}$ diterima.

\section{4) Uji Kesamaan Dua Rerata (Uji-t)}

Untuk menguji hipotesis penelitian maka dilakukan uji dua rata-rata,yaitu uji kesamaan dua rata-rata. Data skor pretes kedua kelas tersebut berdistribusi normal dan memiliki varians yang homogen, selanjutnya dilakukan uji kesamaan dua rerata dengan uji-t dua pihak melalui program software SPSS versi 21.0 menggunakan Independent Sample T-Test dengan asumsi kedua varians homogen (equal varians assumed) dengan taraf signifikansi 0,05. Hipotesis tersebut dirumuskan dalam bentuk hipotesis (uji dua pihak) sebagai berikut.

$$
\begin{gathered}
\mathrm{H}_{0}: \mu_{1}=\mu_{2} \\
\mathrm{H}_{1}: \mu_{1} \neq \mu_{2}
\end{gathered}
$$

Dengan keterangan:

$\mathrm{H}_{0}$ : Kemampuan pemahaman matematik siswa yang mendapat pembelajaran matematika dengan teknik scaffolding sama dengan kemampuan pemahaman matematik siswa yang mendapat pembelajaran matematika dengan konvensional.

$\mathrm{H}_{1}$ : Kemampuan pemahaman matematik siswa yang mendapat pembelajaran matematika dengan teknik scaffolding tidak sama dengan kemampuan pemahaman

$$
\begin{aligned}
& \text { matematik siswa yang mendapat } \\
& \text { pembelajaran matematika dengan } \\
& \text { konvensional. }
\end{aligned}
$$

Dengan menggunakan taraf signifikansi 5\% ( $\alpha=$ $0,05)$ maka kriteria pengujiannya adalah :

a. Nilai Asymp. Sig. (2-tailed) pengujian data lebih kecil dari 0,05, maka $\mathrm{H}_{0}$ ditolak.

b. Nilai Asymp. Sig. (2-tailed) pengujian data lebih besar atau sama dengan dari 0,05, maka $\mathrm{H}_{0}$ diterima.

\section{Analisis Data Hasil Postes \\ 1) Uji Normalitas}

Uji normalitas data pretes kelas eksperimen dan kelas kontrol untuk mengetahui apakah data skor postes berdistribusi normal atau tidak. Normalitas data diperlukan untuk menentukan pengujian perbedaan dua rata-rata. Perumusan hipotesis pengujian normalitas menurut Uyanto (2009: 40) untuk data postesadalah.

$\mathrm{H}_{0}$ : Data skor postesberasal dari populasi yang berdistribusi normal

$\mathrm{H}_{1}$ : Data skor postesberasal dari populasi yang tidak berdistribusi normal

Uji normalitas dengan menggunakan uji Shaphiro-Wilk dengan taraf signifikansi 5\%.Untuk kriteria pengujiannya sebagai berikut.
a. Nilai signifikansi (sig.) pengujian data lebih kecil dari 0,05, maka $\mathrm{H}_{0}$ ditolak.
b. Nilai signifikansi (sig.) pengujian data lebih besar atau sama dengan dari 0,05, maka $\mathrm{H}_{0}$ diterima.

\section{3). Uji Homogenitas Dua Varians}

Setelah uji normalitas data postes menunjukan kedua kelas berasal dari populasi yang berdistribusi normal, selanjutnya dilakukan uji homogenitas dua varians untuk mengetahui apakah kedua data postes mempunyai varians homogen atau tidak. Perumusan hipotesis yang 


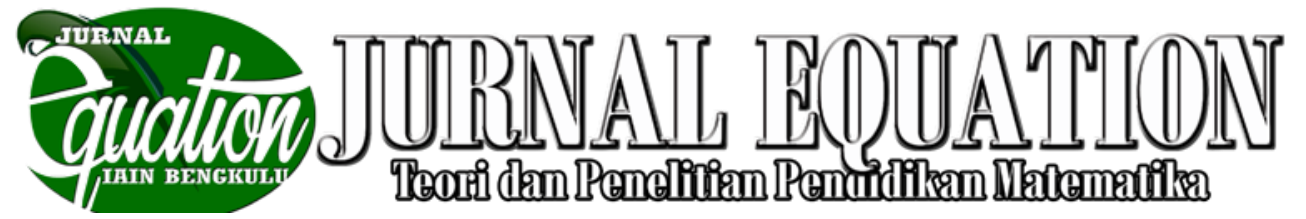

Volume 2 Nomor 2, September 2019, ISSN 2599-3291 (Cetak), ISSN 2614-3933

digunakan pada uji normalitas data postes adalah sebagai berikut.

$\mathrm{H}_{0}$ : Tidak terdapat perbedaan varians antara kelas eksperimen dan kelas kontrol.

$\mathrm{H}_{1}$ : Terdapat perbedaan varians antara kelas eksperimen dan kelas kontrol.

Uji homogenitas yang digunakan adalah uji Levene dengan taraf signifikansi $5 \%$. Kriteria pengujiannya adalah sebagai berikut.

a. Nilai signifikansi (sig.) pengujian data lebih kecil dari 0,05, maka $\mathrm{H}_{0}$ ditolak.

b. Nilai signifikansi (sig.) pengujian data lebih besar atau sama dengan 0,05 , maka $\mathrm{H}_{0}$ diterima.

4). Uji Kesamaan Dua Rerata (Uji-t)

Data skor postes kedua kelas tersebut berdistribusi normal dan memiliki varians yang homogen, selanjutnya dilakukan uji kesamaan dua rerata dengan uji-t dua pihak melalui program software SPSS versi 21.0 menggunakan Independent Sample T-Test dengan asumsi kedua varians homogen (equal varians assumed) dengan taraf signifikansi 0,05. Hipotesis tersebut dirumuskan dalam bentuk hipotesis (uji satu pihak) sebagai berikut.

$$
\begin{aligned}
& H_{0}: \mu_{1}=\mu_{2} \\
& H_{1}: \mu_{1}>\mu_{2}
\end{aligned}
$$

Dengan keterangan :

$\mathrm{H}_{0}$ : Tidak terdapat perbedaan peningkatan kemampuan pemahaman matematik antara siswa yang mendapatkan pembelajaran matematika dengan teknik scaffolding dengan siswa yang mendapat pembelajaran matematika dengan konvensional.

$\mathrm{H}_{1}$ : Peningkatan kemampuan pemahaman matematik siswa yang mendapatkan pembelajaran matematika dengan teknik scaffolding lebih baik daripada siswa yang mendapat pembelajaran matematika dengan konvensional.
Dengan menggunakan taraf signifikansi 5\% ( $\alpha=$ $0,05)$ maka kriteria pengujiannya adalah :

a. Nilai $\frac{1}{2}$ Asymp. Sig. (2-tailed) pengujian data lebih kecil dari 0,05, maka $\mathrm{H}_{0}$ ditolak.

b. Nilai $\frac{1}{2}$ Asymp. Sig. (2-tailed) pengujian data lebih besar atau sama dengan dari 0,05, maka $\mathrm{H}_{0}$ diterima.

\section{Analisis Data Hasil Indeks Gain}

Untuk mengetahui kualitas peningkatan kemampuan pemahaman matematik dari kelas eksperimen dan kelas kontrol dapat dilihat dari data indeks gain. Untuk menentukan indeks gain ternormalisasi (Normalize Gain) digunakan rumus dari Hake (Wahyuni, 2013: 41):

$$
\text { indeks gain }=\frac{\text { skor postes }- \text { skor pretes }}{\text { skormaksimum }- \text { skor pretes }}
$$
pemahaman matematik siswa diperoleh dari data indeks gain. Langkah-langkah yang digunakan untuk menganalisis data peningkatan kemampuan pemahaman matematik adalah sebagai berikut:

\section{1) Uji Normalitas}

Uji normalitas data indeks gain kelas eksperimen dan kelas kontrol untuk mengetahui apakah data skor indeks gain berasal data subjek berdistribusi normal atau tidak. Uji 1Sample K-S (Shapiro-Wilk) dengan taraf signifikansi $5 \%$ adalah uji normalitas yang digunakan dalam penelitian ini dengan bantuan software SPSS versi 21.0.Perumusan hipotesis pengujian normalitas menurut Uyanto (2009: 40) untuk data indeks gain adalah.

$\mathrm{H}_{0}$ : Data skor indeks gain berasal dari populasi yang berdistribusi normal $\mathrm{H}_{1}$ : Data skor indeks gain berasal dari populasi yang tidak berdistribusi normal 


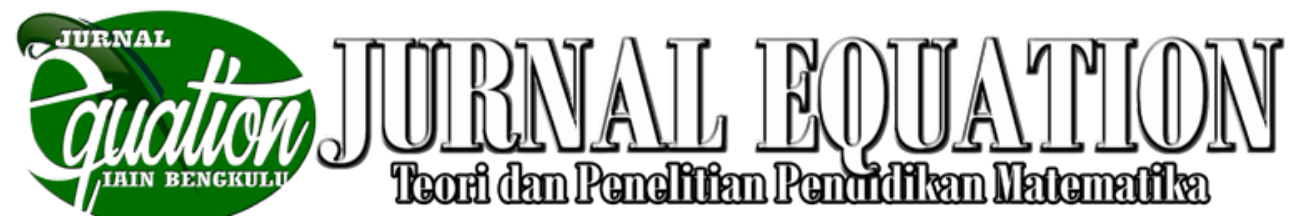

Volume 2 Nomor 2, September 2019, ISSN 2599-3291 (Cetak), ISSN 2614-3933

Uji normalitas dengan menggunakan uji Shaphiro-Wilk dengan taraf signifikansi $5 \%$. Untuk kriteria pengujiannya sebagai berikut.

a. Nilai signifikansi (sig.) pengujian data lebih kecil dari 0,05 , maka $\mathrm{H}_{0}$ ditolak.

b. Nilai signifikansi (sig.) pengujian data lebih besar atau sama dengan dari 0,05, maka $\mathrm{H}_{0}$ diterima.

\section{2) Uji Homogenitas Dua Varians}

Setelah uji normalitas data indeks gain menunjukan kedua kelas berasal dari populasi yang berdistribusi normal, selanjutnya dilakukan uji homogenitas varians untuk mengetahui apakah kedua data indeks gain mempunyai varians homogen atau tidak.Perumusan hipotesis yang digunakan pada uji homogenitas data pretes adalah sebagai berikut.

$\mathrm{H}_{0}$ : Tidak terdapat perbedaan varians antara kelas eksperimen dan kelas kontrol.

$\mathrm{H}_{1}$ : Terdapat perbedaan varians antara kelas eksperimen dan kelas kontrol.

Uji homogenitas yang digunakan adalah uji Lavene dengan taraf signifikansi $5 \%$. Kriteria pengujiannya adalah sebagai berikut.

a. Nilai signifikansi (sig.) pengujian data lebih kecil dari 0,05 , maka $\mathrm{H}_{0}$ ditolak.

b. Nilai signifikansi (sig.) pengujian data lebih besar atau sama dengan 0,05 , maka $\mathrm{H}_{0}$ diterima.

\section{3) Uji Kesamaan Dua Rerata (Uji-t)}

Untuk menguji hipotesis penelitian maka dilakukan uji dua rata-rata,yaitu uji kesamaan dua rata-rata. Data skor indeks gain kedua kelas tersebut berdistribusi normal dan memiliki varians yang tidak homogen, selanjutnya dilakukan uji kesamaan dua rerata dengan uji-t dua pihak melalui program software SPSS versi 21.0 menggunakan Independent Sample T-Test dengan asumsi kedua varians homogen (equal varians not assumed) dengan taraf signifikansi
0,05 . Hipotesis tersebut dirumuskan dalam bentuk hipotesis (uji dua pihak) sebagai berikut.

$$
\begin{gathered}
\mathrm{H}_{0}: \mu_{1}=\mu_{2} \\
\mathrm{H}_{1}: \mu_{1}>\mu_{2}
\end{gathered}
$$

Dengan keterangan:

$\mathrm{H}_{0}$ : Tidak terdapat perbedaan peningkatan kemampuan pemahaman matematik antara siswa yang mendapatkan pembelajaran matematika dengan teknik scaffolding dengan siswa yang mendapat pembelajaran matematika dengan konvensional.

$\mathrm{H}_{1}$ : Peningkatan kemampuan pemahaman matematik siswa yang mendapatkan pembelajaran matematika dengan teknik scaffolding lebih baik daripada siswa yang mendapat pembelajaran matematika dengan konvensional.

Dengan menggunakan taraf signifikansi $5 \%(\alpha=$ $0,05)$ maka kriteria pengujiannya adalah :

a. Nilai $\frac{1}{2}$ Asymp. Sig. (2-tailed) pengujian data lebih kecil dari 0,05 , maka $\mathrm{H}_{0}$ ditolak.

b. Nilai $\frac{1}{2}$ Asymp. Sig. (2-tailed) pengujian data lebih besar atau sama dengan dari 0,05, maka $\mathrm{H}_{0}$ diterima.

\section{Analisis Data Kualitas Peningkatan Kemampuan Pemahaman Matematik Siswa}

Dari data postes dan indeks gain yang telah dianalisis menunjukan bahwa kualitas peningkatan kemampuan pemahaman siswa yang mendapatkan pembelajaran dengan teknik scaffolding lebih baik dibandingkan dengan yang mendapatkan pembelajaran konvensional.

Hasil perhitungan Normalize Gain kemudian diinterpretasikan menggunakan kriteria indeks gain seperti pada Tabel sebagai berikut.

Tabel 1. Kriteria Indeks Gain
\begin{tabular}{|c|c|}
\hline Nilai (g) & Interpretasi \\
\hline $\mathrm{g} \geq 0,7$ & Tinggi \\
\hline
\end{tabular}




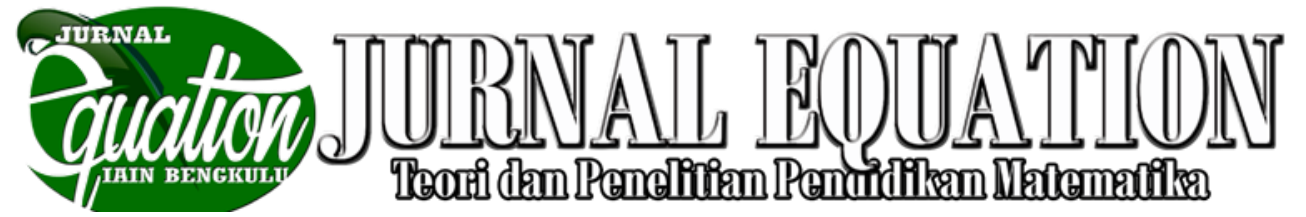

Volume 2 Nomor 2, September 2019, ISSN 2599-3291 (Cetak), ISSN 2614-3933

\begin{tabular}{|c|c|}
\hline Nilai $(\mathrm{g})$ & Interpretasi \\
\hline $0,3 \leq \mathrm{g}<0,7$ & Sedang \\
\hline $\mathrm{g}<0,3$ & Rendah \\
\hline
\end{tabular}

\section{Analisis Data Hasil Angket}

Angket dalam penelitian ini diharapkan benar-benar mewakili sikap dan respon siswa terhadap pernyataan yang diberikan, sehingga penelitian memberikan empat alternatif pilihan jawaban. Angket yang digunakan adalah angket skala Likert yang terbagi ke dalam dua pernyataan, pernyataan positif dan pernyataan negatif. Setiap pernyataan diberikan empat pilihan jawaban, SS (Sangat Setuju), S (Setuju), TS (Tidak Setuju) dan STS (Sangat Tidak Setuju). Untuk setiap pernyatan, pilihan jawaban diberi skor seperti tertera pada Tabel berikut.

Tabel 2. Kriteria Pemberian Skor Pernyataan Angket

\begin{tabular}{|l|c|c|c|c|}
\hline \multirow{2}{*}{ Pernyataan } & \multicolumn{4}{|c|}{ Skor Tiap Pilihan } \\
\cline { 2 - 5 } & SS & S & TS & STS \\
\hline Positif & 5 & 4 & 2 & 1 \\
\hline Negatif & 1 & 2 & 4 & 5 \\
\hline
\end{tabular}

Tahap selanjutnya adalah menghitung skor rata-rata sikap siswa untuk masing-masing butir pernyataan menggunakan rumus berdasarkan Suherman dan Sukjaya (1990: 237), yaitu:

Keterangan:

$$
x=\frac{\sum W F}{F}
$$

$\mathrm{x}=$ Nilai rata-rata

$\sum W F=$ Jumlah siswa yang memiliki setiap kategori

$\mathrm{F} \quad=$ Nilai kategori siswa

Kriteria penilaian sikap diperoleh dari angket ini adalah jika nilai rata-rata sikap siswa lebih besar atau sama dengan dari skor minimalnya $(x \geq 3$ ) maka siswa memberikan sikap yang positif. Sebaliknya, jika nilai rata-rata sikap siswa lebih kecil dari skor minimalnya $(x<3)$ maka siswa memberikan sikap yang negatif (Suherman, 2003: 191).

Kemudian, dilakukan analisis lebih lanjut untuk mengetahui sikap siswa terhadap penggunaaan teknik scaffolding dalam pembelajaran matematika.

\section{1) Uji Normalitas}

Uji normalitas dilakukan untuk menentukan apakah data angket yang diperoleh berdistribusi normal atau tidak. Perumusan hipotesis pengujian normalitas untuk data angket adalah :

$\mathrm{H}_{0} \quad$ : Data angket berasal dari populasi yang berdistribusi normal

$\mathrm{H}_{1} \quad$ : Data angket berasal dari populasi yang tidak berdistribusi normal

Dengan kriteria pengujiannya menurut Uyanto (2009:40) menggunakan taraf signifikan $5 \%(\alpha=0,05)$ maka kriteria pengujian adalah

a. Nilai signifikansi (sig.) pengujian data lebih kecil dari 0,05 , maka $\mathrm{H}_{0}$ ditolak.

b. Nilai signifikansi (sig.) pengujian data lebih besar atau sama dengan dari 0,05, maka $\mathrm{H}_{0}$ diterima.

\section{2). Uji-t Satu Pihak (One Tail Test)}

Untuk menguji hipotesis penelitian maka dilakukan uji dua rata-rata,yaitu uji satu pihak menggunakan uji One-Sample T-Test pada software SPSS versi 21.0dengan taraf signifikansi 0,05 dan nilai yang dihipotesiskan adalah 3. Hipotesis tersebut dirumuskan dalam bentuk hipotesis statistik sebagai berikut:

$$
\begin{aligned}
& \mathrm{H}_{0}: \mu=3 \\
& \mathrm{H}_{1}: \mu>3
\end{aligned}
$$

Dengan keterangan:

$\mathrm{H}_{\mathrm{o}}$ : Siswa tidak bersikap positif terhadap penggunaan teknik scaffolding dalam pembelajaran matematika . 


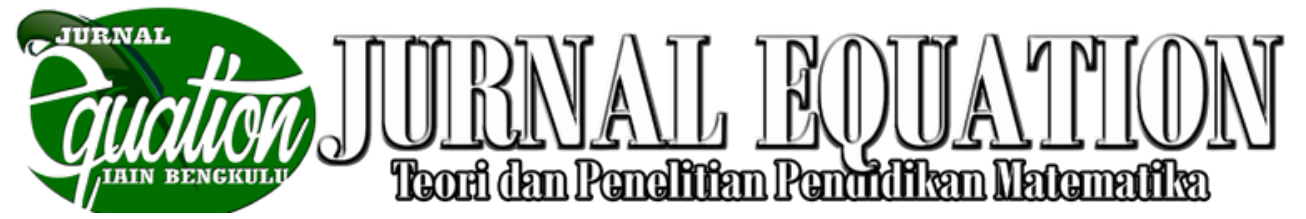

Volume 2 Nomor 2, September 2019, ISSN 2599-3291 (Cetak), ISSN 2614-3933

$\mathrm{H}_{1}$ : Siswa bersikap positif terhadap penggunaan teknik scaffolding dalam pembelajaran matematika.

Adapun kriteria pengambilan keputusan menurut Uyanto (2009: 110) nilai signifikansi dua pihak (2-tailed) yang diperoleh dibagi 2 karena dilakukan uji hipotesis satu pihak (pihak kanan). Dengan menggunakan taraf signifikan 5\% ( $a=$ $0,05)$ maka kriteria pengujiannya adalah

a. Jika nilai $\frac{1}{2}$ taraf signifikansi $\left(\frac{1}{2}\right.$ Sig. $)>0,05$ maka $\mathrm{H}_{0}$ diterima.

b. Jika nilai $\frac{1}{2}$ taraf signifikansi $\left(\frac{1}{2}\right.$ Sig. $) \leq 0,05$ maka $\mathrm{H}_{0}$ ditolak.

\section{HASIL DAN PEMBAHASAN}

Pembahasan dilakukan berdasarkan hasil penelitian dari teori yaitu mengenai kemampuan pemahaman matematik siswa, sikap siswa terhadap pembelajaran dengan teknik scaffolding, dan pelaksanaan pembelajaran dengan teknik scaffolding. Mengenai kemampuan pemahaman matematik siswa, berdasarkan data pretes yang diperoleh rata-rata awal dari kelas eksperimen dan kelas kontrol tidak memiliki perbedaan yang cukup besar yaitu 0,55 . Rata-rata kemampuan awal kelas kontrol lebih rendah dibandingkan dengan rata-rata kelas eksperimen. Pada uji statistik rata-rata skor pretes dengan taraf signifikansi 0,05 diperoleh bahwa rata-rata kemampuan awal pemahaman matematik kedua kelas adalah sama.

Setelah diberikan pembelajaran dengan menggunakan pembelajaran konvensional untuk kelas kontrol dan teknik scaffolding untuk kelas eksperimen siswa diberikan postes. Dari hasil postes yang diperoleh, kedua kelas tersebut memiliki pencapaian yang berbeda pada hasil rata-rata kemampuan pemahaman matematik. Rata-rata skor postes eksperimen adalah 62,43 dan rata-rata skor postes kelas kontrol adalah 56,70 . Perbedaan rata-rata antara kelas kontrol dangan kelas eksperimen adalah 5,73. Rata-rata skor postes kelas eksperimen lebih besar daripada rata-rata skor postes kelas kontrol. Setelah dilakukan uji statistik dengan taraf signifikansi 0,05 diperoleh bahwa pencapaian kemampuan pemahaman matematik siswa kelas eksperimen lebih baik dibandingkan kelas kontrol. Begitu pula dengan peningkatan kemampuan pemahaman matematik kelas eksperimen lebih baik dibandingkan kelas kontrol. Hal ini dapat dilihat dari rata-rata indeks gain kelas eksperimen lebih besar daripada kelas kontrol. Untuk rata-rata gain kelas eksperimen adalah 0,54 dan kontrol adalah 0,47. Kualitas peningkatan kemampuan pemahaman matematik dilihat dari rata-rata indeks gain, ratarata indeks gain untuk kelas eksperimen termasuk kategori sedangdan kelas kontrol termasuk kategori sedang. Dengan demikian dapat disimpulkan bahwa kemampuan pemahaman matematik siswa yang mendapatkan pembelajaran dengan teknik scaffolding lebih baik daripada siswa yang mendapatkan pembelajaran konvensional.

Sikap siswa terhadap pembelajaran dengan teknik scaffolding, dapat dilihat dari hasil analisis angket siswa. Sebagian besar siswa menunjukan sikap positif terhadap pembelajaran dengan teknik scaffolding. Hal ini ditunjukan dari rata-rata skor aspek nomor 1 yang lebih dari 3 yaitu 4,10, rata-rata aspek nomor 2 lebih dari 3 yaitu 4,22 dan rata-rata aspek nomor 3 juga lebih dari 3 yaitu 3,96. Dengan rata-rata keseluruhan aspek adalah 4,10. Berdasarkan hasil pembahasan tersebut dapat disimpulkan bahwa siswa menunjukan sikap positif terhadap pembelajaran dengan teknik scaffolding.

Untuk pelaksanaan pembelajaran dengan teknik scaffolding dapat dilihat dari analisis data lembar observasi. Dari hasil peolehan hasil rata-rata pada penilaian pendahuluan adalah 4,3. Ini menunjukan kriteria 


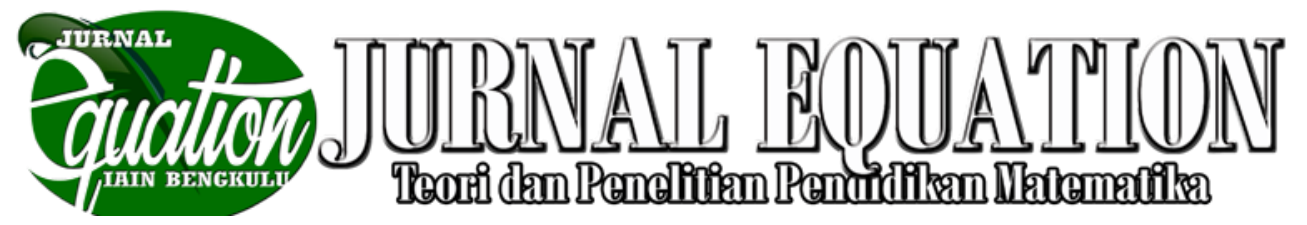

Volume 2 Nomor 2, September 2019, ISSN 2599-3291 (Cetak), ISSN 2614-3933

baik namun pada pertemuan pertama dan kedua guru kurang memberikan motivasi kepada siswa. Rata-rata pada penilaian kegiatan inti adalah 4,2. Ini menunjukan kriteria baik namun pada pertemuan kedua dan keempat guru tidak memberikan waktu yang cukup untuk lebih memahami permasalahan pada LKS karena siswa kesulitan untuk menurunkan rumus belah ketupat dan layang-layang. Selain itu pada kegiatan inti merekam respon siswa persentasenya adalah 4,2, hal yang kurang terlaksana juga terjadi pada pertemuan kedua yaitu guru kurang memberikan kesempatan kepada siswa untuk mempersentasikan hasil diskusi. Rata-rata pada penilaian penutup adalah 3,25 , karena pada beberapa pertemuan tidak terjadi miskonsepsi pada pembelajarannya.

Permasalahan-permasalahan

yang disajikan dalam Lembar Kerja Siswa (LKS) pun membantu siswa dalam meningkatkan kemampuan dalam menyelesaikan soal-soal yang berhubungan dengan kehidupan sehari-hari (pernyataan no. 23) sehingga pada akhirnya, sebagian besar siswa setuju bahwa bahwa mereka ingin mengetahui bermacam-macam cara dalam menyelesaikan cara dalam menyelesaikan soal-soal (pernyataan no. 25).

\section{KESIMPULAN DAN SARAN}

Bedasarkan hasil penelitian yang dilaksanakan mengenai penggunaan teknik scaffolding pada pembelajaran matematika untuk meningkatkan kemampuan pemahaman matematik siswa SMP, diperoleh kesimpulan sebagai berikut.

1. Kemampuan pemahaman matematika siswa yang menggunakan teknik scaffolding lebih baik daripada siswa yang pembelajarannya menggunakan pembelajaran konvensional.
2. Kualitas peningkatan kemampuan pemahaman matematik siswa dengan

menggunakan teknik scaffolding berada pada kategori sedang.

3. Sikap siswa terhadap pembelajaran matematika dengan teknik scaffolding adalah seluruh siswa memberikan sikap yang positif.

Berdasarkan hasil penelitian di lapangan sebelum diberikan metode teknik scaffolding, peneliti menemukan banyak siswa yang hanya dapat mengerjakan soal matematika saja ketika diberikan soal lain yang berbeda dengan permasalahan yang sama ternyata siswa tidak bisa mengerjakannya lagi. Hal ini menunjukan bahwa pemahaman matematik siswa khususnya SMP masih rendah dan perlu diteliti lagi. Maka dari itu peneliti memberikan beberapa saran sebagai berikut:

1. Pembelajaran matematika dengan menggunakan teknik scaffolding dapat digunakan sebagai salah satu alternatif pembelajaran di kelas. Metode pembelajaran ini dapat melatih siswa dan mengembangkan kemampuan pemahaman matematik.

2. Pada penelitian ini peneliti menemukan kecocokan antara teknik scaffolding dengan kemampuan pemahaman matematik dillihat dari hasil penelitiannya. Maka dari itu peneliti menyarankan penggunaan teknik scaffolding dengan pokok bahasan lain dan jenjang selanjutnya untuk mengetahui apakah benar teknik scaffolding itu melatih siswa dan mengembangkan kemampuan pemahaman matematik.

\section{DAFTAR PUSTAKA}

Machmudin, A. A. (2004). Pembelajaran Aplikasi Rumus Geometri dalam Mengerjakan Soal Kelas tiga di SLTP Gemah melalui Pendekatan Pemahaman Konsep. (Skripsi). Bandung: Jurdikmat FPMIPA UP 
Volume 2 Nomor 2, September 2019, ISSN 2599-3291 (Cetak), ISSN 2614-3933

Nengsih, S. (2009). Pengaruh Pendekatan Kontekstual Terhadap Peningkatan Kemampuan Pemahaman Konsep Matematika Siswa SMP. Skripsi Jurusan Matematika FKIP Bandung: tidak diterbitkan.

Nurmasari, N. (2005). Peningkatan Kemampuan Menulis Teks Recount Sederhana melalui Strategi Scaffolding pada Siswa kelas VII-8 SMPN 1 Cibungbulang. Laporan Penelitian Tindakan Kelas. Bogor: Tidak ditertibkan

Priyatni, E. T. (2008). Peningkatan Kompetensi Menulis Paragraf dengan Teknik Scaffolding. [online]. Tersedia: http://sastra.um.ac.id/wpcontent/uploads/2009/10/PeningkatanKompetensi-Menulis-Paragraf-dengan-
Teknik-Scaffolding-Endah-Tri-Priyatni.pdf. [11 Mei 2014]

Ruseffendi, E. T. (1988). Pembelajaran Berbasis Terbuka . Bandung : Tarsito

Suherman, E. dan Sukjaya. (1990). Petunjuk Praktis untuk Melaksanakan Evaluasi Pendidikan Matematika. Bandung: Wijayakusumah.

Uyanto, S.S. (2009). Pedoman Analisis Data dengan SPSS.Yogyakarta. Graha IImu.

Wahyuni. (2013). Penerapan Model Learning Cycle 7E untuk Meningkatkan Kemampuan Pemecahan Masalah Matematis Siswa SMA. Skripsi FPMIPA UPI Bandung: Tidak diterbitkan. 